\title{
Individual and Social Determinants of Water-Pipe Smoking among Medical Student at King Saud University
}

\author{
Dr. Abdul-Aziz bin Abdullah bin Saeed ${ }^{1}$, Ahmed Nagshbandi ${ }^{2}$, Yazeed Aleid ${ }^{3}$, Fahad Almousa ${ }^{4}$ \\ ${ }^{1}$ Family Medicine Consultant, the Deputy Minister of Health for Public Health. \\ ${ }^{2,3,4}$ Co-authors, Medical Interns, King Saud University, College of Medicine, Riyadh, Saudi Arabia.
}

\begin{abstract}
Several factors may contribute to the rising of water-pipe smoking. Objectives: Several factors may contribute to the rising of water pipe smoking. The objectives of our study were to determine the prevalence, individual and social factors of water pipe smoking among undergraduate medical students of King Saud University in Riyadh, Saudi Arabia. Methods: A cross-sectional descriptive/analytical study was done among a representative sample of 408 male and female undergraduate medical students. A simple random sampling method was used to select the participants. Aself-administered questionnaire was constructed based on the National Youth Tobacco Survey in the United States. Multiple logistic regression analysis was performed to analyze the data. Results: The prevalence of water-pipe smoking among medical students was $11.8 \%$ for males and $2 \%$ for females. Factors associated with water pipe smoking were water pipe smoking among siblings $(\mathrm{OR}=6.6 ; 95 \% \mathrm{CI}=2.3-18.2)$,parents $(\mathrm{OR}=4.6 ; 95 \% \mathrm{CI}=1.7-12.0)$, and closefriend $(\mathrm{OR}=65.7 ; 95 \% \mathrm{CI}=8.8-490.0)$. The odds of water pipe smoking among the $5^{\text {th }}$ year students were five times higher $(O R=5.5$; 95\% CI = $1.4-24.6)$ compared to other years. Students whose parents were widowed had 4.2-fold (95\% CI = 1.2- 13.7) odds of water pipe smoking compared to students with full families. Conclusion: Social determinants, such as water pipe smoking among siblings, parents and close friends, as well as individual factors such as years of a study and parental marital status were associated with water pipe smoking among undergraduate medical students. Our finding can potentially improve tobacco control programs in Saudi Arabia and decrease the prevalence of water pipe smoking among students.
\end{abstract}

Keywords: Water pipe, Smoking

\section{Introduction}

Water-pipe (which is called hookah and shisha as well) smoking started in the North Western provinces of India. In addition, Smoking the hookah has spread outside of its native region, in India, Iran, Pakistan and the Middle East, and is gaining popularity in North America, South America, Europe, Australiaand South Africa.

Tobacco smoking (including all forms such as: water pipe smoking and cigarette) is one of the major causes of death worldwide (2). In addition, many chronic diseases can be caused by tobacco smoking especially water pipe smoking such as: Pulmonary, cardiac diseases, several types of cancer and non-neoplastic pathologies(3, 4).Also, 4.9 million deathsa year due to tobacco use was reported by world health organization (WHO) in 2001,there are many researches show that the prevalence of water pipe smoking is increasing in the last few years and it is expected to rise up to 10 million by $2030(5)$.

In 2010, a study shows the prevalence of water pipe smoking was $37.5 \%$ among non-medical students(6)However, it was mentioned that this percentage is influenced by multifactor such as: gender, presence of cigarette and water pipe smoking among family and friends $(5,4)$. It was discovered that the cigarette smokers are less than water pipe smokers among medical students(7). Some school students believe that the water pipe smoking is less harmful than the cigarette in addition to the social acceptance for the water pipe smoking in comparison to cigarette smoking (4).
Furthermore, a study shows that cigarette and water pipe smoking prevalence rate of $61.9 \%$ for males and $10.7 \%$ for females(8). Another study shows that 414 university students were reported as water pipe smokers(9). It was also mentioned that $20.7 \%$ of water pipe smokers smoked on daily basis and $23.8 \%$

Weekly (6). However, the prevalence of smoking among health professionals, including medical students, is higher than the general population (2).

A study showed that the prevalence of water pipe was $28.6 \%$ among medical students; it was influenced by the presence of water pipe smoking among family and friends (5). Another study showed that the overall prevalence of tobacco use among medical students were $10.9 \%$ for cigarette and $23.5 \%$ for water pipe and $7.3 \%$ for both (1). In 2010 , it was reported that $17.6 \%$ of medical students were water pipe smokers (6). Furthermore, it was mentioned that smoking tobacco was in older age medical students than younger age year students $(1,4)$.

In 2011, a study was done among male medical students whichshowed a result of $12.6 \%$ was reported as Shisha smokers and $4 \%$ were smoking both shisha and cigarette. In addition, it was mentioned that the percentage of smokers who started smoking at age $16-18$ years old was $63.8 \%$ and the percentage of daily smokers was $15 \%(10)$.

There are many factors that lead the student to smoke using water-pipe. In 2010 study shows that outings with friends, company, boredom and wasting time considers as a Primary motives of shisha smoking. It is also found that knowledge 


\section{International Journal of Science and Research (IJSR) \\ ISSN (Online): 2319-7064}

Index Copernicus Value (2013): 6.14 | Impact Factor (2014): 5.611

about health hazards of water-pipe smoking was low, regardless of smoking status. Also (37.8\%) believe that it relieves stress and tensions.

\section{Rationale}

Smoking is getting spread over time among the developing countries.A high prevalence of water pipe smoking is shown in these countries, especially among students of middle-aged adults. A study was conducted in KSU has conclude that the prevalence of tobacco smoking among students is $14.5 \%$ (11). Furthermore, tobacco (in both forms of cigarette and water pipe smoking) has a very significant effect on the health. It considered as one of the most factors that causecancers and other serious chronic diseases. We have determined the prevalence of smoking water pipe among medical students at KSU. In addition to the individual and social factors that lead them to smoke.

\section{Methodology}

\section{Study Design}

We have used a cross-sectional study design(quantitative [observational], in order to assess the prevalence and to identify the social and individual factors associated with water pipe smoking among the medical students of the KSU.

\section{Study Setting}

We reached our study population in the lecture halls, after the lectures, and conduct the interview in the nearby available study rooms in the College of Medicine building KSU in Riyadh, Saudi Arabia. We collected the data on Saturday $2^{\text {nd }}$ of February with an estimated duration of 15 days.

\section{Target Population}

We have targeted medical students at KSU including male and female students from all medical years (from $1^{\text {st }}$ until $\left.5^{\text {th }}\right)$.

The medical students who we chose in our pilot study were excluded from the study.

\section{Sampling Design}

We conducted a stratified proportionate random sampling of the study elements from list of students obtained from the Medical Education Department, using a random number generator of MS Excel program (2010)

\section{Sample Size:}

We have conducted the study among 380 medical students.

We used the formula for a single proportion to calculate our sample size. The single proportional formula is:

$$
n=\frac{z_{\alpha}^{2} p(1-p)}{d^{2}}
$$

Where, $\mathrm{d}=$ (precision) $=$ is $5 \%, \mathrm{Z}_{\mathrm{a}}=1.96$ because we used a $95 \%$ confidence interval, $\mathrm{p}=$ (proportion) $=54 \%$, that we got from our literature search (5).

\section{Final Sample Size}

We increased the sample size by $26 \%$ which will result in final sample size of 500 to overcomes low response rate (2)

\section{Data Collection Methods}

We constructed our questionnaire based on different valid and reliable questionnaires regarding tobacco use including from the National Health and Nutrition Examination Survey, World Health Organization Global Youth Tobacco Survey, and Oxford Happiness Questionnaire.

Our questionnaire was divided into three main sections which are personal data, smoking history and possible social and individual factors, in personal data section we will ask about the main data e.g. age, gender, residency and socioeconomic status of the subjects and their families. While in smoking history section we will try to figure out if they have ever tried water-pipe smoking or other type of smoking and the age of starting, frequency and the amount of smoking. Social and individual factors section we will explore the social and individual factors by asking about the cause, the purpose and if there are any triggers to smoke. Also we want to know if there is any relation between living alone far from the family and smoking. To determine social factors, we will ask our subjects if their family members or close friends are smokers and the effect of advertising in the internet, news paper and television of being a smoker. At the end we will ask smoker subjects if they intend to quit smoking or not.

\section{Pilot Study}

We distributed a pilot study on 20 medical students to test the questionnaire and logistics of data collection, suitability / clarity of data collection tools, estimation of timing for data collection and then they were excluded from the study.

\section{Study Variables}

The outcome of the study is to measure water-pipe smoking status among medical students at KSU. Also we studied the effect of social and individual factors on medical students at KSU who smoke water pipe such as ; gender, family residency, family exposure, close friend exposure, socioeconomic state, advertising in the (internet, news paper and television), etc.

\section{Data Analysis}

Data were coded and analyzed by using SPSS version 21 to do some descriptive statistic, cross tables and weighting the variables. Also, the Odds ratios were obtained by using Epi Info software version 3.5.4.

\section{Ethical Considerations}

1) Participants anonymity was assured by using code numbers rather than names for analysis only.

2) Written consent was obtained from the respondents, and they were informed them that they can refuse to participate or answer on any question at any point.

3) No incentives or rewards were given to participant.

4) This study was approved by the Institutional Review Board of the King Saud University.

\section{Results}

\section{Background Data}

Out of 500 medical students approached, both males and females, 408 students completed the questionnaire, with a 


\section{International Journal of Science and Research (IJSR) \\ ISSN (Online): 2319-7064 \\ Index Copernicus Value (2013): 6.14 | Impact Factor (2014): 5.611}

response rate of about $81.5 \%$. There were 209 male and 198 female participants from the first to the fifth year in approximately equal percentages of the medical school with mean age of 21.6 (SD 1.45) for male and 21.83 (SD 1.53) for female. Most of the students' families (89.7\%) were living in Riyadh and the majority of them around (97\%) were single and with little percent of married student the female $(4.4 \%)$ was much more than male $(0.8 \%)$. In addition, most of the students $(90.7 \%)$ were living with their families and approximately half of them had an household income of more than SAR 25,000. As seen in Table1, 71.6\% of students were physically inactive or had some light physical activity, with males generally more physically active than females and the BMI level tend to be more in males than females (26.5 vs. 22.5).

\section{Prevalence of Smoking}

The overall number of regular water-pipe smokers was 25 $(11.8 \%)$ of male and $4(2 \%)$ of female medical students (Table 2). However, there was small percentage of cigarette smoking among male students only (6.8\%). Moreover, most of the male students who were currently smoke water-pipe they started to smoke before college $(52.4 \%)$ unlike all of the females that tend to start smoking after joining the college.(Table XXX). However, 56 (26.9\%) of male and 21 $(10.6 \%)$ of female responded that they did try water-pipe in the past, but only small percentage of them continuo to smoke. On the other hand, there were a good percentage of the overall family members who smoke in general $(43.6 \%)$ of male family member and (52\%) of female family member. Also, water-pipe smoking among students' fathers was $(4.9 \%)$ in male and $(6.6 \%)$ in females and the mothers and brother also had some percentages of water-pipe smoking.

\section{Prevalence of Happiness}

In Table (3), the study show in different type of happiness level among the medical student including male and female. Most of male $(71.7 \%)$ and female $(66.1 \%)$ disagreed on feeling of unpleased. Also, (76.5\%) male and (83.3\%) female agreed upon felt that life is rewarding and (76.6\%) male and $(81.8 \%)$ female agreed on their satisfaction about everything. Moreover, (66\%) male and (81.2\%) female disagreed on didn't think that they look attractive and also $(78.1 \%)$ male and $(87.5 \%)$ female disagreed on didn't have happy memory in the past. Furthermore, most of the male and female student agreed in finding beauty in life, can fit in everything that they want and feeling of fully mental alter.

\section{Individual Factors}

Table 4 shows the effects of the individual factors (Medical year, marital status, current living, total income and parent current marital status) on water-pipe smoking among medical students. Medical year show a fluctuation trend that start from 1 st year by (3.4\%) and increased in second year to $(5.1 \%)$ and decreased in 3 rd and $4^{\text {th }}$ to $(4.2 \%)$ year and finally a big increased in 5 th year $(16.9 \%)$ with significant OR $($ Odds Ratio $)=(5.46)$ and $95 \%$ CI (Confidence Interval) $=(1.42-24.57)$, so the risk to smoke water-pipe is five time higher when being in 5th year than the others. Almost every current water-pipe smoker was single in compare to married smoker. The study shows those water-pipe smokers who living in dormitory $(8.7 \%)$ have more risk to smoke waterpipe than whom living with their families $(6.2 \%)$ with $(\mathrm{OR}=$ $1.44 ; 95 \% \mathrm{CI}=0.15-6.5)$. The total income of the household seems to have no risk in being water-pipe smoker as the study shows almost equal income to all current smokers. However, our study shows that if the parent status were widow $(22.7 \%)$ the risk of being water-pipe smoker is four time more than if the parent were married with $(\mathrm{OR}=4.22$; $95 \% \mathrm{CI}=1.23-13.68)$. Furthermore, the majority of current water-pipe smokers have started smoking before joining the college $(52.4 \%)$ and the rest was started through the studying years.

\section{Social factors}

There are so many social factors that can be associated with water-pipe smoking among medical students such as (family member smoking including the parents and sibling, number of close friends who are smoker, physical activity in leisure time and the mood of the person and how happy helshe is). In Table 5, it shows that the number of water-pipe smoker who had a family member smoker $(9.3 \%)$ was more than in case of no family member smoke $(4.8 \%)$ with $(\mathrm{OR}=2.01$; $95 \% \mathrm{CI}=0.85-4.83)$. In addition, specifically there was about four times risk increase of water-pipe smoking if the parents were water-pipe smoker $(22.6 \%)$ in compare to the parents who were non smoker $(6 \%)$ with $(\mathrm{OR}=4.56 ; 95 \% \mathrm{CI}$ $=1.68-11.96)$ ). Surprisingly, our study shows that the effect of sibling (brother and sister) is very high by which if the sibling were water-pipe smoker the risk were about six times to be a water-pipe smoker $(29.17 \%)$ in compare to who smoke with non smoker siblings (brother and sister) $(5.85 \%)$ with ( $\mathrm{OR}=6.63 ; 95 \% \mathrm{CI}=2.34-18.25)$. However, the effect of close friends is also considered to be high as the number of water-pipe smoker with smoker friend $(20.3 \%)$ is much more than with non smoker friend $(0.4 \%)$ with ( OR = $65.72 ; 95 \% \mathrm{CI}=9.37-1316.56)$. Moreover, physical activity during leisure time were found to effect the water-pipe smoker in which number of smokers in hard physically active students $(16 \%)$ were higher than number of smokers whom physically inactive $(4.2 \%)$ with $(\mathrm{OR}=4.34 ; 95 \% \mathrm{CI}=$ 0.89-20.88) In regarding the happiness status of the student, there were no much significantly difference between waterpipe smoker and non smoker. 


\section{International Journal of Science and Research (IJSR) \\ ISSN (Online): 2319-7064 \\ Index Copernicus Value (2013): 6.14 | Impact Factor (2014): 5.611}

Table 1: Socio-Demographic Characteristics for Water-pipe smoking among KSU medical student, 2013

\begin{tabular}{|c|c|c|}
\hline Variables & Male (209) & Female(198) \\
\hline Age $($ Mean \pm SD) & $21.6 \pm 1.45$ & $21.83 \pm 1.53$ \\
\hline BMI (Mean \pm SD) & $26.54 \pm 5.87$ & $22.45 \pm 4.40$ \\
\hline \multicolumn{3}{|l|}{ Family living, N (\%) } \\
\hline $\begin{array}{l}\text { Riyadh } \\
\text { Other }\end{array}$ & $\begin{array}{l}180(88.3 \%) \\
24(11.7 \%)\end{array}$ & $\begin{array}{l}186(94 \%) \\
6(3 \%)\end{array}$ \\
\hline \multicolumn{3}{|l|}{ Medical year, N (\%) } \\
\hline $\begin{array}{l}1^{\text {st }} \\
2^{\text {nd }} \\
3^{\text {rd }} \\
4^{\text {th }} \\
5^{\text {th }}\end{array}$ & $\begin{array}{l}43(20.8 \%) \\
36(17.3 \%) \\
39(18.5 \%) \\
36(17.3 \%) \\
54(26.1 \%)\end{array}$ & $\begin{array}{l}44(22.3 \%) \\
42(21.1 \%) \\
32(16.3 \%) \\
35(17.5 \%) \\
45(22.9 \%)\end{array}$ \\
\hline \multicolumn{3}{|l|}{ Marital Status, N (\%) } \\
\hline $\begin{array}{l}\text { Single } \\
\text { Married } \\
\text { Engaged }\end{array}$ & \begin{tabular}{|l|}
$207(99.2 \%)$ \\
$2(0.8 \%)$ \\
0
\end{tabular} & $\begin{array}{l}187(94.6 \%) \\
9(4.4 \%) \\
2(1 \%)\end{array}$ \\
\hline \multicolumn{3}{|c|}{ Income of entire household (SAR), N (\%) } \\
\hline $\begin{array}{l}5,000 \text { or less } \\
5,001-15,000 \\
15,001-25,000 \\
25,001-35,000 \\
35,001-45,000 \\
45,001 \text { or more }\end{array}$ & \begin{tabular}{|l|}
$14(6.9 \%)$ \\
$37(17.8 \%)$ \\
$47(22.7 \%)$ \\
$26(12.5 \%)$ \\
$30(14.2 \%)$ \\
$47(22.8 \%)$ \\
\end{tabular} & $\begin{array}{l}6(3 \%) \\
28(14.1 \%) \\
31(15.7 \%) \\
29(14.6 \%) \\
35(17.7 \%) \\
59(29.8 \%)\end{array}$ \\
\hline \multicolumn{3}{|l|}{ Current living, N (\%) } \\
\hline $\begin{array}{l}\text { Dormitory } \\
\text { With family } \\
\text { Other }\end{array}$ & $\begin{array}{l}21(10 \%) \\
179(85.7 \%) \\
7(3.5 \%)\end{array}$ & $\begin{array}{l}3(1.5 \%) \\
191(96.5 \%) \\
4(2 \%)\end{array}$ \\
\hline \multicolumn{3}{|c|}{ Parent's current marital status, N (\%) } \\
\hline $\begin{array}{l}\text { Married } \\
\text { Divorced } \\
\text { Separated } \\
\text { Widowed }\end{array}$ & $\begin{array}{l}184(88.4 \%) \\
6(2.7 \%) \\
1(0.4 \%) \\
16(7.7 \%)\end{array}$ & \begin{tabular}{|l|}
$171(86.4 \%)$ \\
$11(5.6 \%)$ \\
$5(2.5 \%)$ \\
$6(3 \%)$ \\
\end{tabular} \\
\hline
\end{tabular}

Table 2: Smoking profile for Water-pipe smoking among KSU medical student, 2013

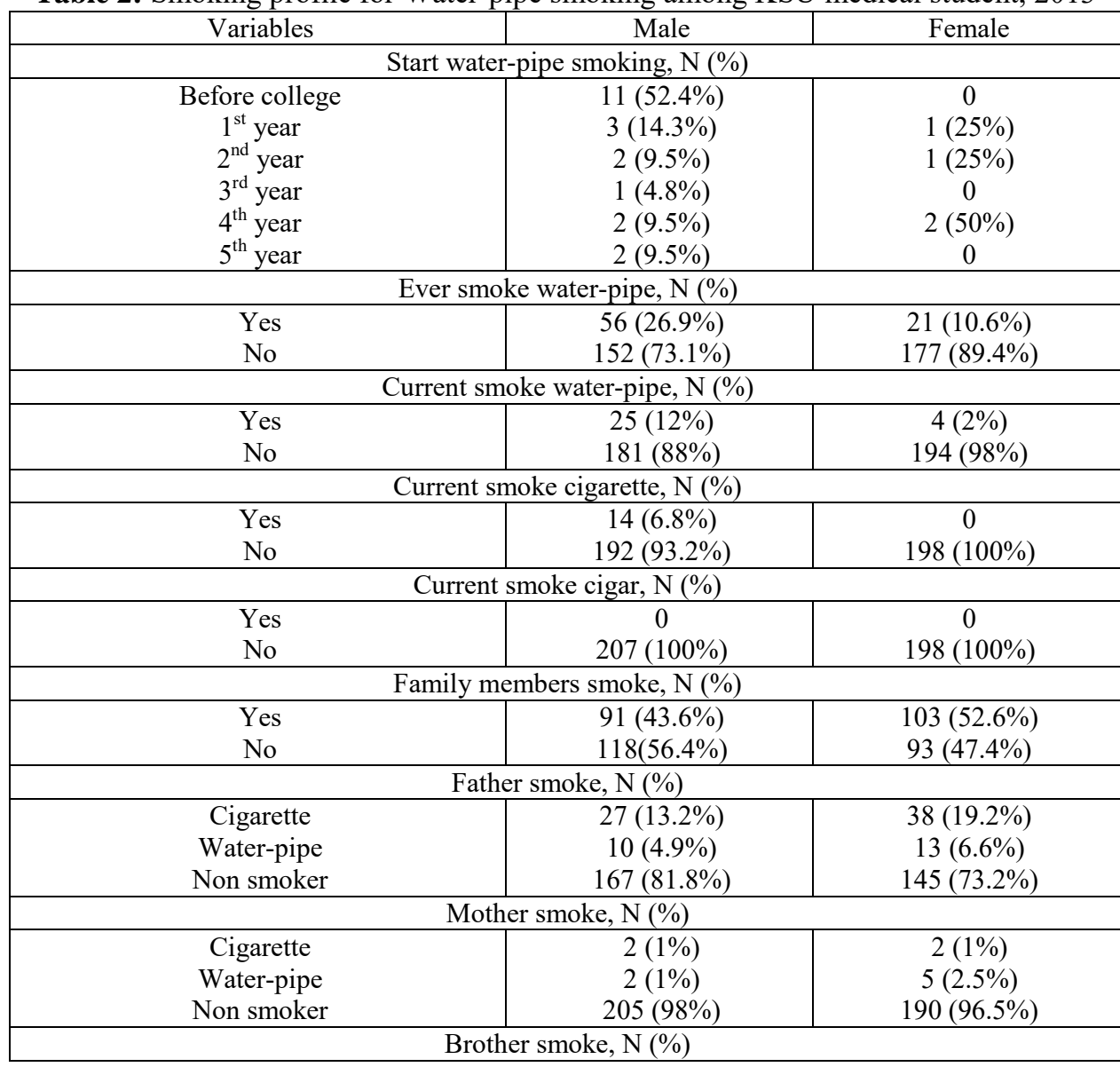

Volume 5 Issue 1, January 2016

www.ijsr.net 
International Journal of Science and Research (IJSR)

ISSN (Online): 2319-7064

Index Copernicus Value (2013): 6.14 | Impact Factor (2014): 5.611

\begin{tabular}{|c|c|c|}
\hline $\begin{array}{c}\text { Cigarette } \\
\text { Water-pipe } \\
\text { Non smoker }\end{array}$ & $\begin{array}{c}42(20.1 \%) \\
10(4.7 \%) \\
147(70.4 \%)\end{array}$ & $\begin{array}{c}38(19.2 \%) \\
6(3 \%) \\
146(73.7 \%)\end{array}$ \\
\hline \multicolumn{3}{|c|}{ Sister smoke, N (\%) } \\
\hline $\begin{array}{c}\text { Cigarette } \\
\text { Water-pipe } \\
\text { Non smoker }\end{array}$ & $\begin{array}{c}2(0.8 \%) \\
2(1.1 \%) \\
205(98.1 \%)\end{array}$ & $\begin{array}{c}1(0.5 \%) \\
5(2.5 \%) \\
192(97 \%)\end{array}$ \\
\hline \multicolumn{3}{|c|}{ Other smoke, N (\%) } \\
\hline $\begin{array}{c}\text { Cigarette } \\
\text { Water-pipe } \\
\text { Non smoker }\end{array}$ & $\begin{array}{c}5(2.4 \%) \\
0 \\
203(97.1 \%)\end{array}$ & $\begin{array}{c}8(4 \%) \\
5(2.5 \%) \\
180(90.9 \%)\end{array}$ \\
\hline
\end{tabular}

Table 3: Individual Factors for Water-pipe smoking among KSU medical student, 2013

\begin{tabular}{|c|c|c|}
\hline Variables & Male & Female \\
\hline \multicolumn{3}{|c|}{ I don’t feel particularly pleased...., N (\%) } \\
\hline Disagree & $142(71.7 \%)$ & $127(66.1 \%)$ \\
\hline Agree & $56(28.3 \%)$ & $65(33.9 \%)$ \\
\hline \multicolumn{3}{|c|}{ I feel that life is very rewarding, $\mathrm{N}(\%)$} \\
\hline Disagree & $46(23.5 \%)$ & $32(16.7 \%)$ \\
\hline Agree & $150(76.5 \%)$ & $160(83.3 \%)$ \\
\hline \multicolumn{3}{|c|}{ I am well satisfied about everything, N (\%) } \\
\hline Disagree & $46(23.4 \%)$ & $35(18.2 \%)$ \\
\hline Agree & $151(76.6 \%)$ & $157(81.8 \%)$ \\
\hline \multicolumn{3}{|c|}{ I don't think I look attractive, N (\%) } \\
\hline Disagree & $128(66 \%)$ & $156(81.2 \%)$ \\
\hline Agree & $66(34 \%)$ & $36(18.8 \%)$ \\
\hline \multicolumn{3}{|c|}{ I find beauty in some things, N (\%) } \\
\hline Disagree & $19(9.7 \%)$ & $16(8.4 \%)$ \\
\hline Agree & $177(90.3 \%)$ & $175(91.6 \%)$ \\
\hline \multicolumn{3}{|c|}{ I can fit in everything I want to, $\mathrm{N}(\%)$} \\
\hline Disagree & $47(24 \%)$ & $52(26.9 \%)$ \\
\hline Agree & $149(76 \%)$ & $141(73.1 \%)$ \\
\hline \multicolumn{3}{|c|}{ I feel fully mentally alert, $\mathrm{N}(\%)$} \\
\hline Disagree & $40(20.4 \%)$ & $33(17.4 \%)$ \\
\hline Agree & $156(79.6 \%)$ & $157(82.6 \%)$ \\
\hline \multicolumn{3}{|c|}{ I do not have particularly happy..., N (\%) } \\
\hline Disagree & $153(78.1 \%)$ & $168(87.5 \%)$ \\
\hline (Agree) & $43(21.9 \%)$ & $24(12.5 \%)$ \\
\hline \multicolumn{3}{|c|}{ Physical activity during leisure time, N (\%) } \\
\hline Physically inactive & $46(22.2 \%)$ & $75(37.9 \%)$ \\
\hline Some light physical activity & $91(43.6 \%)$ & $80(40.4 \%)$ \\
\hline Regular physical activity and training & $41(19.7 \%)$ & $24(12.1 \%)$ \\
\hline Regular hard physical training for competition sports & $18(8.7 \%)$ & $7(3.5 \%)$ \\
\hline
\end{tabular}

Volume 5 Issue 1, January 2016 www.ijsr.net 


\section{International Journal of Science and Research (IJSR) \\ ISSN (Online): 2319-7064 \\ Index Copernicus Value (2013): 6.14 | Impact Factor (2014): 5.611}

Table 4: Individual factors for Water-pipe smoking among KSU medical student, 2013

\begin{tabular}{|c|c|c|c|}
\hline Variables & \multicolumn{3}{|c|}{ Water pipe smoker } \\
\hline Medical year & Yes & No & OR $(95 \% \mathrm{CI})$ \\
\hline First & $3(3.4 \%)$ & $84(96.6 \%)$ & Reference \\
\hline Second & $4(5.1 \%)$ & $74(94.9 \%)$ & $2.38(0.43-14.13)$ \\
\hline Third & $3(4.2 \%)$ & $68(95.8 \%)$ & $1.24(0.19-7.97)$ \\
\hline Fourth & $3(4.2 \%)$ & $68(95.8 \%)$ & $1.24(0.19-7.97)$ \\
\hline Fifth & $16(16.3 \%)$ & $82(83.7 \%)$ & $5.46(1.42-24.57)$ \\
\hline \multicolumn{4}{|l|}{ Marital status } \\
\hline Single & $27(6.9 \%)$ & $365(93.1 \%)$ & Reference \\
\hline Married & $1(10 \%)$ & $9(90 \%)$ & $1.50(0.03-11.55)^{*}$ \\
\hline Engaged & $1(50 \%)$ & $1(50 \%)$ & $13.52(0.17-1063.81)^{*}$ \\
\hline \multicolumn{4}{|l|}{ Current living } \\
\hline With family & $23(6.2 \%)$ & $347(93.8 \%)$ & Reference \\
\hline Dormitory & $2(8.7 \%)$ & $21(91.3 \%)$ & $1.44(0.15-6.5)^{*}$ \\
\hline Other & $3(33.3 \%)$ & $6(66.7 \%)$ & $7.54(1.39-37.25)$ \\
\hline \multicolumn{4}{|c|}{ Income of household (SAR) } \\
\hline 5,000 or less & $2(10 \%)$ & $18(90 \%)$ & Reference \\
\hline $5,001-15,000$ & $4(6.2 \%)$ & $61(93.8 \%)$ & $0.59(0.08-5.10)$ \\
\hline $15,001-25,000$ & $2(2.6 \%)$ & $76(97.4 \%)$ & $0.24(0.02-2.57)$ \\
\hline $25,001-35,000$ & $1(1.8 \%)$ & $55(98.2 \%)$ & $0.16(0.01-2.52)$ \\
\hline $35,001-45,000$ & $5(7.7 \%)$ & $60(92.3 \%)$ & $0.75(0.11-6.15)$ \\
\hline More than 45,000 & $13(12.3 \%)$ & $93(87.7 \%)$ & $1.26(0.24-8.84)$ \\
\hline \multicolumn{4}{|c|}{ Parent current marital status } \\
\hline Married & $23(6.5 \%)$ & $330(93.5 \%)$ & Reference \\
\hline Divorced & & $17(100 \%)$ & ------- \\
\hline Separated & & $6(100 \%)$ & ------ \\
\hline Widowed & $5(22.7 \%)$ & $17(77.3 \%)$ & 4.22(1.23-13.68) \\
\hline \multicolumn{4}{|l|}{ Start smoking } \\
\hline Before college & $10(24.4 \%)$ & $31(75.6 \%)$ & Reference \\
\hline First & $4(33.3 \%)$ & $8(66.7 \%)$ & $1.55(0.31-7.57)$ \\
\hline Second & $4(50 \%)$ & $4(50 \%)$ & $3.10(0.52-19.04)$ \\
\hline Third & $1(25 \%)$ & $3(75 \%)$ & $1.03(0.02-14.64)^{*}$ \\
\hline Fourth & $5(100 \%)$ & & ------- - \\
\hline Fifth & $3(30 \%)$ & $7(70 \%)$ & $1.33(0.22-7.49)$ \\
\hline
\end{tabular}

*Fisher Exact

Table 5: Social factors for Water-pipe smoking among KSU medical student, 2013

\begin{tabular}{|c|c|c|c|}
\hline Variables & Water pipe & & \\
\hline Family members smoke & Yes, N (\%) & No, N (\%) & OR $(95 \% \mathrm{CI})$ \\
\hline Yes & $18(9.3 \%)$ & $176(90.7 \%)$ & $2.01(0.85-4.83)$ \\
\hline No & $10(4.8 \%)$ & $197(95.2 \%)$ & Reference \\
\hline Parents smoke & & & \\
\hline Water-pipe & $7(22.6 \%)$ & $24(77.4 \%)$ & $4.56(1.68-11.96)$ \\
\hline Non smoker & $42(6 \%)$ & $657(94 \%)$ & Reference \\
\hline Sibling smoke & & & \\
\hline Water-pipe & $7(29.17 \%)$ & $17(70.83 \%)$ & $6.63(2.34-18.25)$ \\
\hline Non smoker & $40(5.85 \%)$ & $644(94.15 \%)$ & Reference \\
\hline I don't feel particularly $p$ & & & \\
\hline Disagree & $17(6.3 \%)$ & $252(93.7 \%)$ & Reference \\
\hline Agree & $8(6.6 \%)$ & $113(93.4 \%)$ & $1.04(0.44-2.50)$ \\
\hline I feel that life is very rew & & & \\
\hline Disagree & $7(9.1 \%)$ & $70(90.9 \%)$ & Reference \\
\hline Agree & $18(5.8 \%)$ & $292(94.2 \%)$ & $0.61(0.24-1.53)$ \\
\hline I am well satisfied about & & & \\
\hline Disagree & $8(10 \%)$ & $72(90 \%)$ & Reference \\
\hline Agree & $17(5.5 \%)$ & $292(94.5 \%)$ & $0.52(0.21-1.26)$ \\
\hline I don't think I look attrac & & & \\
\hline Disagree & $17(6 \%)$ & $267(94 \%)$ & Reference \\
\hline Agree & $7(6.9 \%)$ & $95(93.1 \%)$ & $1.15(0.46-2.87)$ \\
\hline I find beauty in some thir & & & \\
\hline Disagree & $2(5.9 \%)$ & $32(94.1 \%)$ & Reference \\
\hline Agree & $22(6.2 \%)$ & $331(93.8 \%)$ & $1.06(0.23-6.86)$ \\
\hline
\end{tabular}

Volume 5 Issue 1, January 2016 
International Journal of Science and Research (IJSR)

ISSN (Online): 2319-7064

Index Copernicus Value (2013): 6.14 | Impact Factor (2014): 5.611

\begin{tabular}{|c|c|c|c|}
\hline $\begin{array}{l}\text { Disagree } \\
\text { Agree }\end{array}$ & $\begin{array}{l}5(5.1 \%) \\
19(6.5 \%)\end{array}$ & $\begin{array}{l}93(94.9 \%) \\
272(93.5 \%)\end{array}$ & $\begin{array}{l}\text { Reference } \\
1.3(0.44-4.1)\end{array}$ \\
\hline \multicolumn{4}{|l|}{ I feel fully mentally alert } \\
\hline $\begin{array}{l}\text { Disagree } \\
\text { Agree }\end{array}$ & $\begin{array}{l}7(9.7 \%) \\
17(5.4 \%)\end{array}$ & $\begin{array}{l}65(90.3 \%) \\
297(94.6 \%)\end{array}$ & $\begin{array}{l}\text { Reference } \\
0.53(0.21-1.48)\end{array}$ \\
\hline \multicolumn{4}{|l|}{ I do not have particularly happy memories of the past } \\
\hline $\begin{array}{l}\text { Disagree } \\
\text { Agree }\end{array}$ & $\begin{array}{l}22(6.9 \%) \\
2(3 \%)\end{array}$ & $\begin{array}{l}299(93.1 \%) \\
65(97 \%)\end{array}$ & $\begin{array}{l}\text { Reference } \\
0.42(0.07-1.9)\end{array}$ \\
\hline \multicolumn{4}{|l|}{ Physical activity during leisure time } \\
\hline $\begin{array}{l}\text { Physically inactive } \\
\text { Some light physical activity } \\
\text { Regular physical activity and training } \\
\text { Regular hard physical training for competition sports }\end{array}$ & $\begin{array}{l}5(4.2 \%) \\
12(7 \%) \\
5(7.7 \%) \\
4(16 \%)\end{array}$ & $\begin{array}{l}114(95.8 \%) \\
159(93 \%) \\
60(92.3 \%) \\
21(84 \%)\end{array}$ & $\begin{array}{l}\text { Reference } \\
1.72(0.54-5.78) \\
1.90(0.45-7.95) \\
4.34(0.89-20.88)\end{array}$ \\
\hline \multicolumn{4}{|l|}{ Close friends smoker } \\
\hline $\begin{array}{l}\text { Yes } \\
\text { No }\end{array}$ & $\begin{array}{l}27(20.3 \%) \\
1(0.4 \%) \\
\end{array}$ & $\begin{array}{l}106(79.7 \%) \\
258(99.6 \%)\end{array}$ & $\begin{array}{l}\text { 65.72(9.37-1316.56) } \\
\text { Reference }\end{array}$ \\
\hline
\end{tabular}

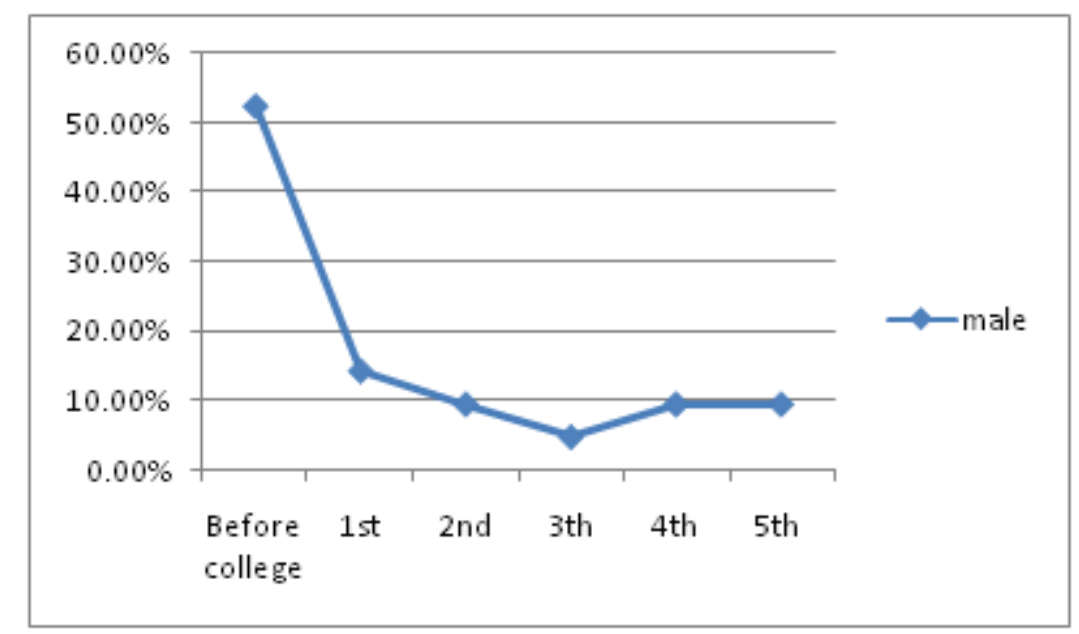

Male trend of starting water-pipe smoking

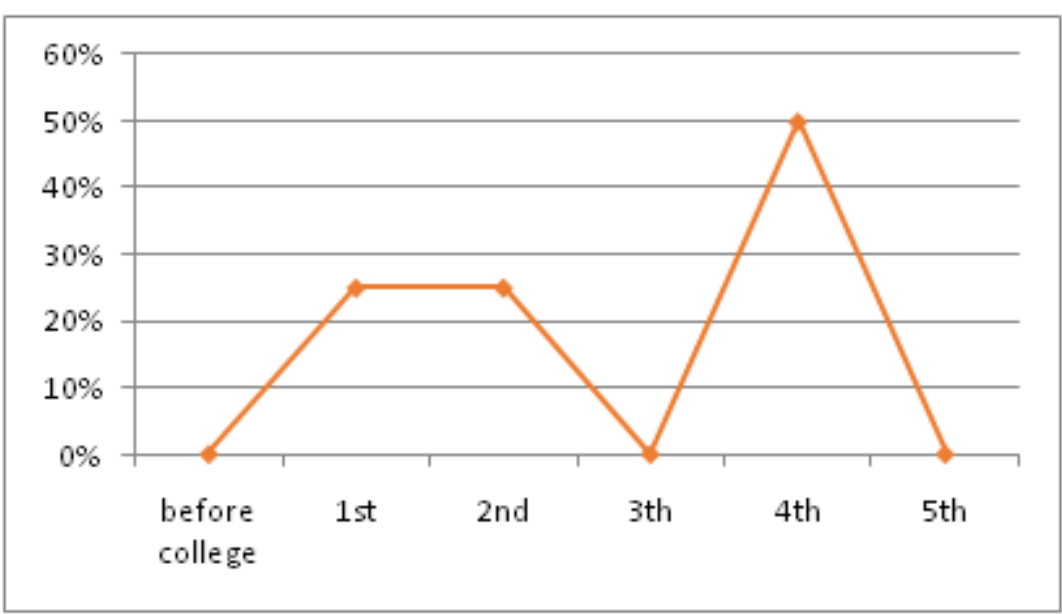

Female trend of starting water-pipe smoking

Volume 5 Issue 1, January 2016

www.ijsr.net 
International Journal of Science and Research (IJSR)

ISSN (Online): 2319-7064

Index Copernicus Value (2013): 6.14 | Impact Factor (2014): 5.611

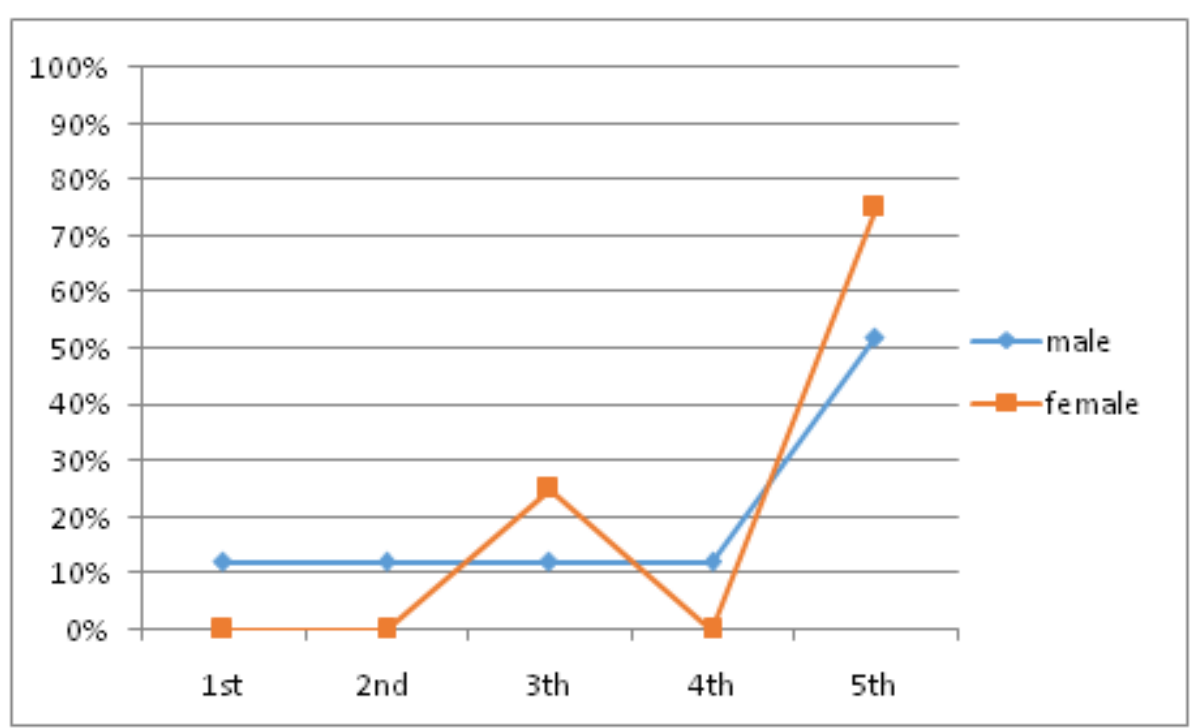

Trend shows the prevalence of smoking throughout all medical year among students

\section{Discussion}

Several factors may contribute to the rising of water-pipe use in the popularity. Water-pipe is cheap and widely available, facilitating its use among youth and individuals. In 2010, a study shows the prevalence of water pipe smoking was $37.5 \%$ among non-medical students(6) and a study shows that cigarette and water pipe smoking prevalence rate of $61.9 \%$ for males and $10.7 \%$ for females(8), Another study shows that 414 university students were reported as water pipe smokers (9) the study showed among Medical students it was reported that the prevalence of water pipe was $28.6 \%(5)$ which shows that is our estimate indicate the prevalence of smoking water pipe less in KSU medical students $12.1 \%$. In 2011, a study was done among male medical students which showed results of $12.6 \%$ were reported as Shisha smokers and 4\% were smoking both shisha and cigarette. This seems to agree with our estimate of $12 \%$ male students are water pipe smoker.

Therewith, such estimates are still high among young educated adults who should be role models for their community, fighting tobacco use rather than using it.

In bivariate analysis showed that the parents' marital statues significantly influenced the practice of smoking water pipe among medical students in our study. Further analysis showed marital status did not significantly influence the practice of water pipe smoking among Malaysian University Students (8). In addition, we noticed some statistically significant raising trend of water-pipe Smoking a risk of $1^{\text {st }}$ year students to $5^{\text {th }}$ year students which the prevalence in $1^{\text {st }}$ year is $3.4 \%$ and it became $16 \%$ in $5^{\text {th }}$ year. It similar with finding was reported in Smoking among Saudi university students study (7). Furthermore, we observed is the living status is a significant and our study showed increasing of water pipe smoking in whom living in dormitory $(8.7 \%)$ or alone without family(33.3\%)more than those living with their family $(6.2 \%)$. There is a study showed that the living status did not significant in smoking among university students (8). As well, in our study we noticed also the Income of household is not a significant in water pipe smoking. Nevertheless, in another study finding that the students with high family income had a higher practice of water pipe smoking compared to those with lower monthly family income(8).

There is a significant association between having a family member smoker and becoming a water-pipe smoker. We found in our study that the effect of the parents who smoke water-pipe on being a water-pipe smoker is $\operatorname{high}(22.6 \%)$ with OR (4.56), also the effect of the sibling who smoke water-pipe is high(29.17\%) with more significant OR (6.63).In addition, a similar finding was reported from Saudi study of smoking tobacco among Saudi university students ${ }^{(11)}$ in which the effect of the parents who smoke water-pipe on being a water-pipe smoker was almost similar(26.22\%) and the effect of the sibling who smoke water-pipe $(24.7 \%)$ is slightly lower significant in compare to our study. Also in our study, the effect of close friends who smoke water-pipe on being a water-pipe smoker is significant $(20.3 \%)$ but not as significant as what was reported from Saudi study of smoking tobacco among Saudi university students ${ }^{(11)}$ which shows the effect of peer pressure (having a smoking friend) on being a smoker is $(32 \%)$. Furthermore, there is an interesting finding in our study which is $81.8 \%$ of water-pipe smokers are physically active ranging from some light physical activity to Regular hard physical training for competition sports which is not explained by other studies.

\section{Conclusion and Recommendations}

The initiation of water-pipe smoking among KSU medical students while studying in the university is $63 \%$.According to our study we found out those most relevant risk factors is the effect of family members (parents, sibling) and close friends among medical student. Also many studies shows that tobacco smoking including water-pipe started increasing among medical students who supposed to be more educated about the tobacco toxicity and the outcome diseases. Finally, the communities should work hardly to know the real predisposing factors for tobacco smoking including waterpipe and why it is increasing among educated people (medical students) and starting the prevention programs to reduce the incidence and the prevalence of tobacco use 


\section{International Journal of Science and Research (IJSR) \\ ISSN (Online): 2319-7064 \\ Index Copernicus Value (2013): 6.14 | Impact Factor (2014): 5.611}

including water-pipe smoking and to educate and advise the people to quit smoking because they don't only harm themselves, they actually harm everybody around them fromsons, daughters, brothers, sisters and friends.

\section{References}

[1] Almerie MQ, Matar HE, Salam M, Morad A, Abdulaal M, Koudsi A, et al. Cigarettes and waterpipe smoking among medical students in Syria: a cross-sectional study. The international journal of tuberculosis and lung disease : the official journal of the International Union against Tuberculosis and Lung Disease. 2008;12(9):1085-91. Epub 2008/08/21.

[2] La Torre G, Kirch W, Bes-Rastrollo M, Ramos RM, Czaplicki M, Gualano MR, et al. Tobacco use among medical students in Europe: results of a multicentre study using the Global Health Professions Student Survey. Public health. 2012;126(2):159-64. Epub 2011/12/20.

[3] Mehrotra R, Chaudhary AK, Pandya S, Mehrotra KA, Singh M. Tobacco use by Indian medical students and the need for comprehensive intervention strategies. Asian Pacific journal of cancer prevention : APJCP. 2010;11(2):349-52. Epub 2010/09/17.

[4] Amin TT, Amr MA, Zaza BO, Suleman W. Harm perception, attitudes and predictors of waterpipe (shisha) smoking among secondary school adolescents in Al-Hassa, Saudi Arabia. Asian Pacific journal of cancer prevention : APJCP. 2010;11(2):293-301. Epub 2010/09/17.

[5] Poyrazoglu S, Sarli S, Gencer Z, Gunay O. Waterpipe (narghile) smoking among medical and non-medical university students in Turkey. Upsala journal of medical sciences. 2010;115(3):210-6. Epub 2010/07/20.

[6] Khan AA, Dey S, Taha AH, Huq FS, Moussawi AH, Omar OS, et al. Attitudes of Cairo University medical students toward smoking: the need for tobacco control programs in medical education. The Journal of the Egyptian Public Health Association. 2012;87(1-2):1-7. Epub 2012/03/15.

[7] Dar-Odeh NS, Bakri FG, Al-Omiri MK, Al-Mashni HM, Eimar HA, Khraisat AS, et al. Narghile (water pipe) smoking among university students in Jordan: prevalence, pattern and beliefs. Harm reduction journal. 2010;7:10. Epub 2010/05/26.

[8] Al Moamary MS, Al Ghobain MA, Al Shehri SN, Alfayez AI, Gasmelseed AY, Al-Hajjaj MS. The prevalence and characteristics of water-pipe smoking among high school students in Saudi Arabia. Journal of infection and public health. 2012;5(2):159-68. Epub 2012/05/01.

[9] Taha AZ, Sabra AA, Al-Mustafa ZZ, Al-Awami HR, Al-Khalaf MA, Al-Momen MM. Water pipe (shisha) smoking among male students of medical colleges in the eastern region of Saudi Arabia. Annals of Saudi medicine. 2010;30(3):222-6. Epub 2010/04/30.

[10] Mohammed HR, Zhang Y, Newman IM, Shell DF. Waterpipe smoking in Kuwait. Eastern Mediterranean health journal $=$ La revue de sante de la Mediterranee orientale $=$ al-Majallah al-sihhiyah li-sharq almutawassit. 2010;16(11):1115-20. Epub 2011/01/12.
[11] Mandil A, BinSaeed A, Dabbagh R, Shaikh SA, AlSaadi M, Khan M. Smoking among Saudi university students: consumption patterns and risk factors. Eastern Mediterranean health journal 2011;17(4):309-16. Epub 2012/01/21. 